\title{
New records of variegated mud-loving beetles (Coleoptera: Heteroceridae) for Vietnam
}

\author{
Alexey S. SAZHNEV \\ Papanin Institute for Biology of Inland Waters of the Russian Academy of Sciences, Borok, 152742 Russia; \\ e-mail:sazh@list.ru
}

\begin{abstract}
New faunistic records of Heteroceridae from Vietnam are provided. Augyles gabriellae Mascagni, 1993 is recorded for the first time for Vietnam.
\end{abstract}

Key words: fauna, distribution, Vietnam, Coleoptera, Heteroceridae, Augyles gabriellae

\section{INTRODUCTION}

Family Heteroceridae includes 5 genera and about 370 species worldwide (Mascagni 2014, Skalický \& Ezer 2014). Adults and larvae of Heteroceridae construct tunnels in wet sand and soil at the edges of streams, rivers, lakes and ponds, and in brackish mud flats (Vanin et al. 2016, Taşar 2014, 2018). The last preliminary list of variegated mud-loving beetles of Vietnam included 9 species and subspecies (Mascagni et al. 2017): Augyles anulatus (Mascagni, 1991); A. gigas Mascagni, Thanh Binh et Ha 2017; A. hiekei Mascagni, 1995; A. infimus (Fairmaire, 1889); A. manfredjaechi (Mascagni, 1995); Heterocerus fenestratus (Thunberg, 1784); H. lorenzevae Mascagni, 1993; H. nepalensis Mascagni, 1993 and H.philippensis ssp. javanicus (Grouvelle, 1896) (Fairmaire 1889, Mascagni 1991, 1995b, Mascagni et al. 2017, Mascagni \& Skalický 2007). The records of Micilus minutissimus Sahlberg, 1900 needs confirmation (Mascagni 2003, Mascagni et al. 2017).

\section{MATERIAL AND METHODS}

The material has been collected as results of expeditions of the Joint Russia-Vietnam Complex Expedition in different years (including 2018). Majority of collected beetles are stored in the Collection of aquatic invertebrates of the Papanin Institute for Biology of Inland Waters, Russian Academy of Sciences, (Borok, Russia, IBIW), while one specimen (holotypus of Augyles letovi Sazhnev, 2018) are kept in the Zoological Institute of the Russian Academy of Sciences (St.-Petersburg, Russia, ZISP).

Photographs of the beetles and the localities were taken using Olympus GT-5 digital camera. Images were generated and enhanced by using PHOTOSHOP ${ }^{\circ}$.

\section{RESULTS}

The updated check-list of the species of variegated mud-loving beetles of Vietnam is presented below in a systematic order.

Family Heteroceridae MacLeay, 1825

Genus Augyles Schiödte, 1866 


\section{Augyles (Augyles) anulatus (Mascagni, 1991)}

Literature. Hanoi (Mascagni 1995b).

Material examined. Vietnam: Prov. Đồng Nai, NNE Ho Chi Minh, env. Cat Tien, 810 Jul 1995, 1 ( coll. A. Napolov, IBIW), in moss, 7-10 Jul 1995, 1 + (coll. A. Napolov, IBIW).

Note. First record for Southern Vietnam and Đồng Nai Province.

Distribution. Cambodia, Thailand, Vietnam (Mascagni 1991, 1995b, Skalický 1999).

\section{Augyles (Augyles) gabriellae (Mascagni, 1993)}

(Fig. 1)

Material examined. Vietnam: Prov. Hòa Bình, UV light, 15 Jan 1976, 1 (coll. L. Medvedev, IBIW); Prov. Đồng Nai, NNE Ho Chi Minh, env. Cat Tien, 8-10 Jul 1995, $1 \overbrace{}^{\star}$ (coll. A. Napolov, IBIW).

Note. First record for Vietnam!

Distribution. Cambodia, Indonesia (Java), Laos, Nepal, Thailand (Mascagni, 1993; Skalický, 2000b, 2005a, 2010a), Vietnam (new record).

\section{Augyles (Augyles) gigas Mascagni, Thanh Binh \& Ha, 2017}

Literature. Hai Duong (Mascagni et al. 2017).

Distribution. Vietnam (Mascagni et al. 2017).

\section{Augyles (Augyles) hiekei (Mascagni, 1995)}

Literature. Chiem-Hoa, Hanoi (Mascagni 1995b).

Material examined. Vietnam: Prov. Hòa Bình, UV light, 15 Jan 1976, 1ðึ, 2 q (coll. L. Medvedev, IBIW), in moss, 18 Jan 1976, $1 \delta^{\Uparrow}$ (coll. L. Medvedev, IBIW).

Note. First record for Hòa Bình Province.

Distribution. India, Laos, Vietnam (Mascagni 1995b, Skalický 2000b, 2001a).

\section{Augyles (Augyles) infimus (Fairmaire, 1889)}

Literature. "Tonkin" (Fairmaire 1889).

Distribution. Vietnam (Fairmaire 1889).

\section{Augyles (Augyles) manfredjaechi (Mascagni, 1995)}

Literature. Nam Cat Tien National Park, $40 \mathrm{~km}$ NW An Khe Buon Luoi (Mascagni 2003).

Distribution. Bangladesh, China, Hong Kong, India, Myanmar, Nepal, Pakistan, Vietnam (Mascagni 1995a, 1995b, 2003, Mascagni \& Sforzi 1999, Skalický 2000a, 2005b, 2012).

\section{Augyles (Augyles) letovi Sazhnev, 2018}

Material examined. Vietnam: Holotypus - Prov. Hòa Bình, UV light, 15 Jan 1976, $1 \delta^{\lambda}$ (coll. L. Medvedev, ZISP). Paratypus - in moss, 18 Jan 1976, 1 ㅇ (coll. L. Medvedev, IBIW). 


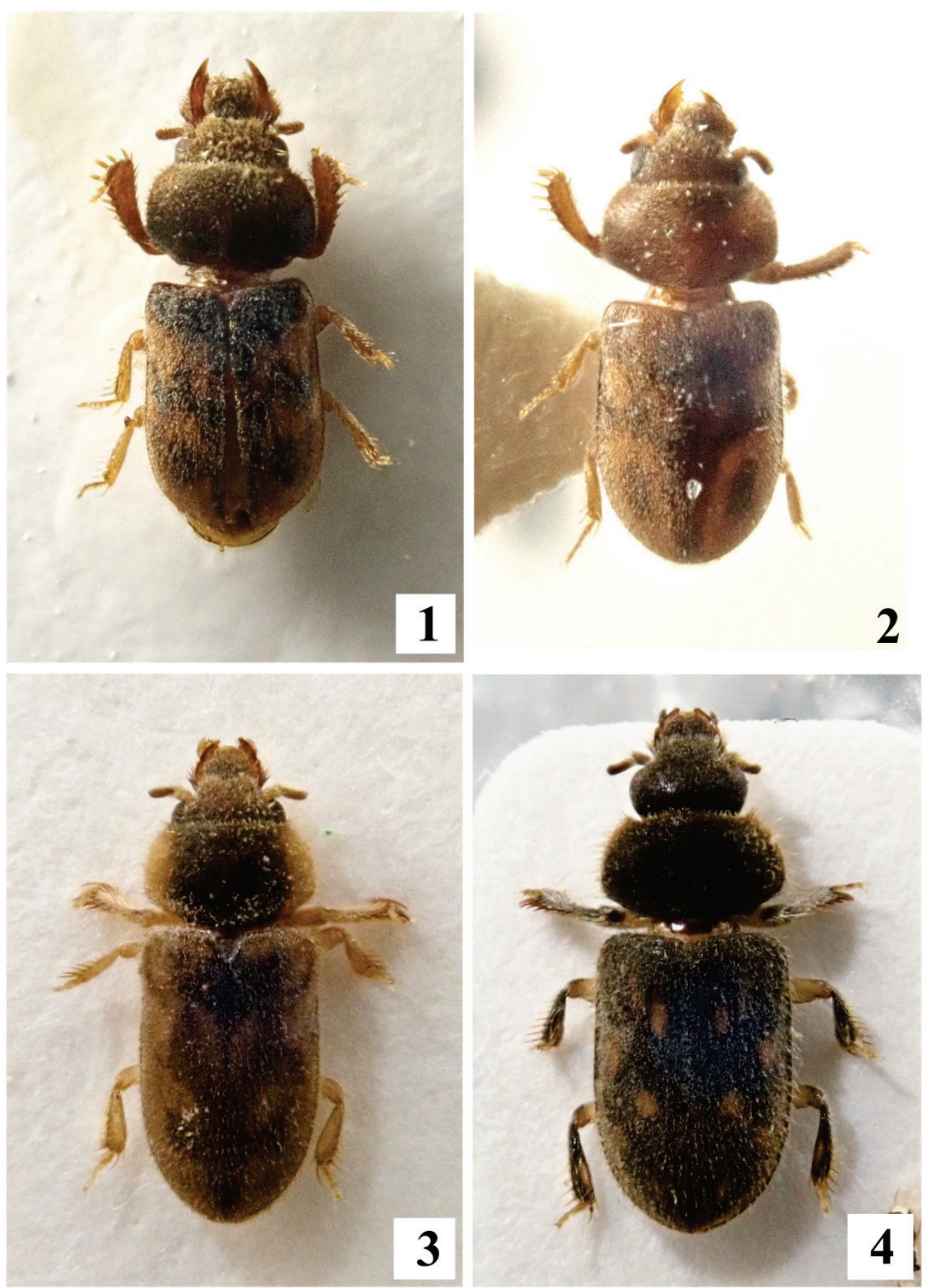

Figs 1-4. Heteroceridae from Vietnam. 1 - Augyles gabriellae, male; 2 - Augyles hiekei, female; 3 - Heterocerus nepalensis, male; 4 - Heterocerus lorenzevae, male. 
Genus Heterocerus Fabricius, 1792

\section{Heterocerus fenestratus (Thunberg, 1784)}

Literature."Tonkin" (Charpentier 1979); Hanoi (Mascagni 1995b); Thanh Moi (Mascagni 1995); Phu Tho (Mascagni et al. 2017); Bac Kan (Mascagni et al. 2017); Cuc Phuong National Park (Mascagni et al. 2017).

Distribution. Holarctic species (Larson 2014; Taşar \& Mascangi 2014; Mascagni 2016; Sazhnev 2016). On territory of Oriental Region Heterocerus fenestratus is distributed in Laos, Philippines, Thailand, Vietnam (Skalický 1999, 2000b, 2012; Freitag et al. 2016; Mascagni et al. 2017).

\section{Heterocerus nepalensis Mascagni, 1993}

(Fig. 3)

Literature. Hanoi (Mascagni 1995a); Cuc Phuong (Mascagni 1995b).

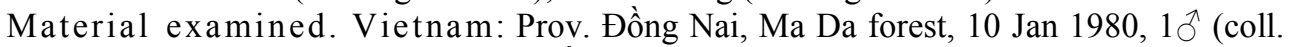
L. Medvedev, IBIW); env. Vinh An, Hồ Trị An Reservoir, duct of Dong Nai River, $11^{\circ} 05^{\prime} 57.6^{\prime \prime} \mathrm{N} 107^{\circ} 01^{\prime} 29.0^{\prime \prime} \mathrm{E}$, rock-pools in riverbed downstream of the dam, 9 May 2018 , $2 \widehat{\jmath}, 1$, (coll. A. Sazhnev, IBIW).

Note. First record for Southern Vietnam and Đồng Nai Province. Specimens were collected on the stony bank and chippings of rock-pools in riverbed (Figs $5 \& 6$ ) together with Carabidae (Tachys sp.), Hydrophilidae (Coelostoma sp., Helochares sp.) and Heterocerus lorenzevae Mascagni 1993.

Distribution. Oriental Region (India, Laos, Myanmar, Sumatra, Thailand, Vietnam), China, Hong Kong, Kyrgyzstan, Nepal, Pakistan, Turkmenistan (Mascagni 1995a, 1995b, 2003, 2016, Mascagni \& Sforzi 1999, Skalický 2000a, 2000b, 2003, 2010a, 2010b).

\section{Heterocerus lorenzevae Mascagni, 1993}

(Fig. 4)

Literature. Nam Cat Tien National Park (Mascagni 2003).

Material examined. Vietnam: Prov. Đồng Nai, Vinh An env., Hồ Trị An Reservoir,

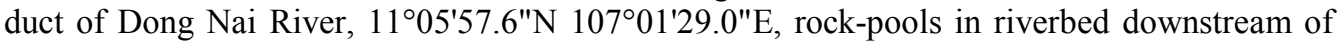
the dam, 9 May 2018, $1 \hat{\jmath}$ (coll. A. Sazhnev, IBIW).

Distribution. Bangladesh, India, Laos, Myanmar, Nepal, Pakistan, Thailand, Vietnam (Mascagni 1993, 1995b, Mascagni \& Sforzi 1999, Skalický 2000a, 2000b, 2001b, 2005b, 2012).

\section{Heterocerus philippensis ssp. javanicus (Grouvelle, 1896)}

Literature. Cuc Phuong (Mascagni 2003, Mascagni \& Skalický 2007); Ben En National Park (Mascagni 2003; Mascagni \& Skalický 2007).

Distribution. India, Indonesia (Java, Nias), Nepal, Pakistan, Thailand, Vietnam (Mascagni \& Skalický 2007, Skalický 2010a).

Genus Micilus Mulsant \& Rey, 1872

\section{Micilus minutissimus Sahlberg, 1900}

Literature. Yen Bai (Mascagni 2003).

Note. Records from Vietnam need confirmation (Mascagni et al. 2017). 
Distribution. India (Uttarakhand), Tajikistan, Turkmenistan, Uzbekistan, Vietnam (Mascagni 2016).

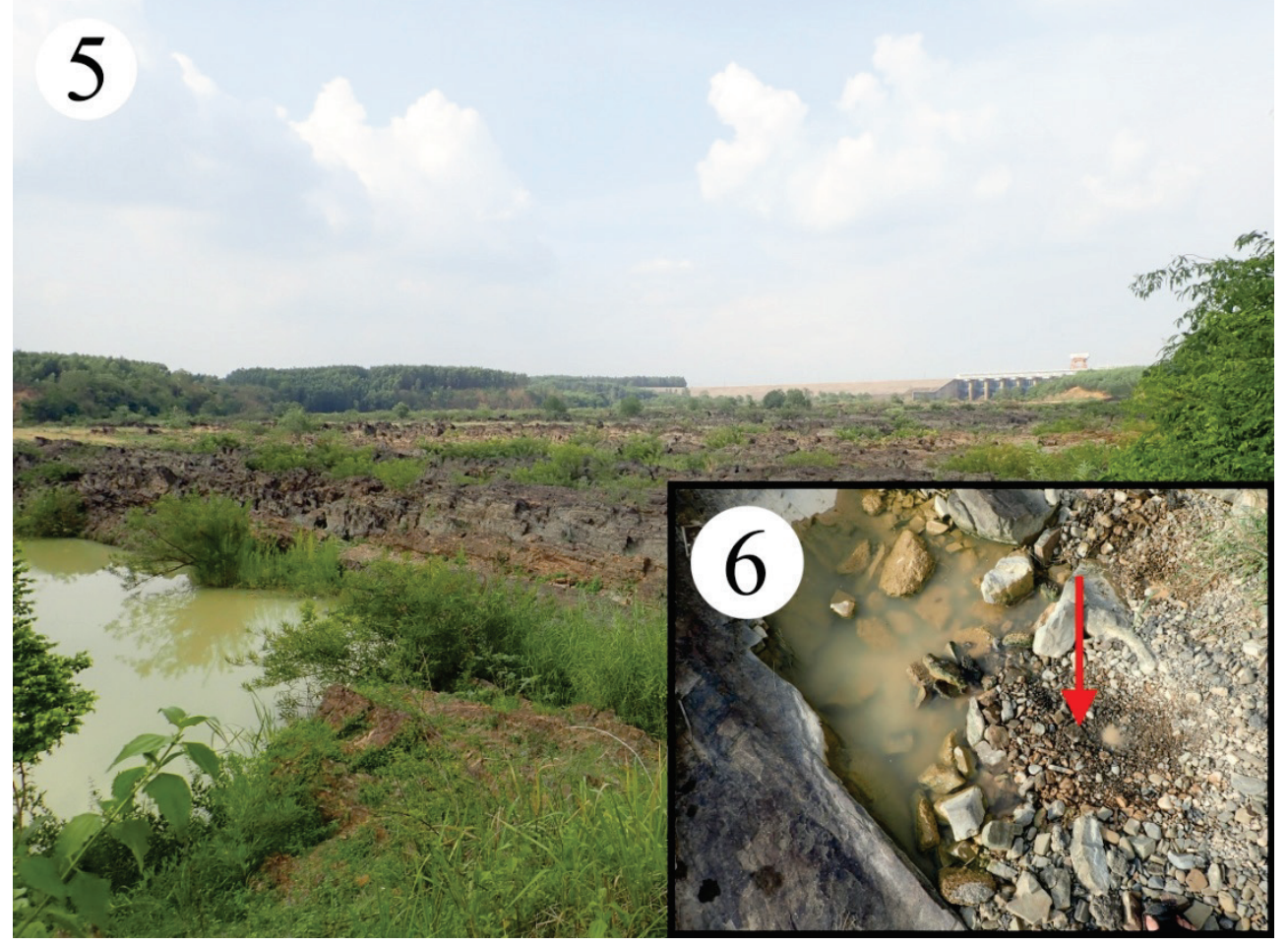

Figs 5-6. Habitats of Heterocerus nepalensis and Heterocerus lorenzevae in Vietnam. 5 - General view of the duct Dong Nai River and dam of Hồ Trị An Reservoir, 6 - One of rock-pools in riverbed downstream.

\section{CONCLUSIONS}

The fauna of the variegated mud-loving beetles of Vietnam is one of the little-studied in South-Eastern Asia, and the list of Heteroceridae of Vietnam now has 11 species, excluding the records of Micilus minutissimus Sahlberg, 1900 needs confirmation. Almost all records of Heteroceridae in the south of Vietnam belong to the territory of the Đồng Nai National Park (Cat Tien, and Ma Da forest). Probably of national parks also helps support native habitats and the high species diversity of variegated mud-loving beetles.

\section{ACKNOWLEDGEMENTS}

The author is grateful for help in conveyed the collection material to Ilya S. Turbanov (Borok, Russia) and Alexander A. Prokin (Borok, Russia). The expedition works, analysis of material and preparing of manuscript was performed in the framework of research program of the Russian-Vietnam Tropical and Research Center (the project Ecolan 3.2).

\section{REFERENCES}

CHARPENTIER R. 1979. Heteroceridae (Coleoptera) from Mongolia with description of Heterocerus kaszabi n. sp. and Heterocerus interspidulus n. sp. Entomologica Scandinavica 10 (3): 229-237.

FAIRMAIRE L. 1889. Descriptions de Coléoptères de 1'Indo-Chine. Annales de la Société Entomologique de France (6) 8 [1888]: 333-378. 
Freitag H., JÄCh M. A. \& WeWalka G. 2016. Diversity of aquatic and riparian Coleoptera of the Philippines: checklist, state of knowledge, priorities for future research and conservation. Aquatic Insects 37(3): 177-213.

LARSON D. J. 2014. Key to Saskatchewan Species of Heteroceridae. Entomological Society of Saskatchewan. Web resource: http://www.entsocsask.ca/insect_lists.html

MASCAGNi A. 1991. Contributo alla conoscenza degli Heteroceridae del Burma e della Cambogia con descrizione di Heterocerus anulatus n. sp. (Insecta: Coleoptera: Heteroceridae). Redia 74 (1): 15-28.

MASCAGNi A. 1993. Quattro nuove specie ed una nuova sottospecie di Heteroceridae dell'Asia (Coleoptera). Opuscula zoologica fluminensia 112: 1-11.

Mascagni A. 1995a. Contributo alla conoscenza degli Heteroceridae del Nepal, con descrizione di sei nuove specie (Coleoptera). Opuscula zoologica fluminensia 135: 1-12.

MASCAGNi A. 1995b. Heteroceridae: Check list of the Heteroceridae of China and neighbouring countries, and description of two new species (Coleoptera). In: JÄCH M. A. \& JI L. (eds), Water Beetles of China. Vol. 1, pp. 341-348. Zoologisch-Botanische Gesellschaft in Österreich and Wiener Coleopterologenverein, Vienna, $410 \mathrm{pp}$.

Mascagni A. 2003. Descriptions of three new species, and updated checklist of the Heteroceridae of China and neighbouring countries (Coleoptera: Heteroceridae). Koleopterologische Rundschau 73: 285-296.

MascaGni A. 2014. The Variegated Mud-Loving Beetles of Europe (first part) (Coleoptera: Heteroceridae). Onychium 10: 78-118.

MASCAGNi A. 2016. Family Heteroceridae MacLeay, 1825. In: LöBL I. \& LöBL D. (eds), Catalogue of Palaearctic Coleoptera. Vol. 3, Scarabaeoidea, Scirtoidea, Dascilloidea, Buprestoidea, Byrrhoidea. Leiden; Boston: Brill, 984 pp.

MASCAGNI A. \& SFORZI A. 1999. Contribution to the knowledge of Heteroceridae from India and neighbouring countries (Coleoptera: Heteroceridae). Koleopterologische Rundschau 69: 111-117.

Mascagni A. \& SKALICKÝ S. 2007. New species and new statuses of Heteroceridae from the Oriental region (Coleoptera). Folia Heyrovskyana, Series A, 14 (3): 87-94.

Mascagni A., Thanh Binh T. T. \& Ha N. T. 2017. A new species of Augyles Schiödte, 1866 from Vietnam (Coleoptera: Heteroceridae). Koleopterologische Rundschau 87: 283-287. DOI: 10.11646/zootaxa.4521.4.9

SAZHNEV A.S. 2016. Heterocerus kamtschaticus A. Egorov, 1989 is a new synonym of the Holarctic H. fenestratus (Thunberg, 1784) (Coleoptera: Heteroceridae). Zoosystematica Rossica 25 (1): 163-164.

SAZHNEV A. S. 2018. A new species of the genus Augyles Schiödte, 1866 (Coleoptera: Heteroceridae) from Vietnam. Zootaxa 4521 (4): 597-599. DOI: 10.11646/zootaxa.4521.4.9

SKALICKÝ S. 1999. New species of Heteroceridae from Thailand and Namibia (Coleoptera: Heteroceridae). Koleopterologische Rundschau 69: 119-123.

SKALICKÝ S. 2000a. New species and new faunistic records of Heteroceridae from Myanmar (Coleoptera: Heteroceridae). Koleopterologische Rundschau 70: 185-189.

SKALICKÝ S. 2000b. New Augyles species and subspecies from Laos and Thailand (Coleoptera: Heteroceridae). Opuscula zoologica fluminensia 187: 1-11.

SKALICKÝ S. 2001a. Notes on Indian Heteroceridae (Coleoptera), with description of Augyles pucholti sp. n. Klapalekiana 37: 53-57.

SKALICKÝ S. 2001b. Augyles skalei sp.n. and notes on Heteroceridae (Coleoptera) from Nepal. Folia Heyrovskyana 9 (3-4): 211-216.

SkALICKÝ S. 2003. Two new species of Augyles from India (Heteroceridae). Koleopterologische Rundschau 73: 297-300.

SKALICKÝ S. 2005a. New and little known species of Heteroceridae from Java (Coleoptera: Heteroceridae). Koleopterologische Rundschau 75: 349-358.

SKALICKÝ S. 2005b. New species and new records of Heteroceridae from Pakistan (Insecta: Coleoptera). Mitteilungen des Internationalen Entomologischen Vereins e.V. Frankfurt am Main, 30 (3/4): 133-142.

SKALICKÝ S. 2010a. Heteroceridae: Checklist of the taxa recorded from Indonesia and the Southwest Pacific (Coleoptera). Pp: 395-400. In: JÄCH M. A. \& BALKE M. (eds.), Water beetles of New Caledonia (part 1). Monographs on Coleoptera 3. Zoologisch-Botanische Gesellschaft (Section of Entomology): Wiener Coleopterologenverein, Vienna, IV+449 pp.

SKAliCKÝ S. 2010b. Augyles gerdmuelleri n. sp. from Kirghizia (Coleoptera, Heteroceridae). Entomologishe Blätter 106: 365-369.

SKALICKÝ S. 2012. Augyles barborae sp.n. from Lantau Island (Hong Kong), and new faunistic records of Heteroceridae from Hong Kong (Coleoptera: Heteroceridae). Koleopterologische Rundschau 82: 311-315.

SKALICKÝ S. \& Ezer E. 2014. Coleoptera: Heteroceridae. Folia Heyrovskyana, Serie B., Icones Insectorum Europae Centralis 18: 1-12.

TASAR G. E. \& MASCAGNi A. 2014. Checklist of Heteroceridae (Coleoptera) of Turkey. Pakistan Journal of Zoology 46 (6): 1685-1690.

TAŞAR G. E. 2014. A Contribution to the Knowledge of Turkish Dryopidae, Elmidae and Heteroceridae (Coleoptera: Byrrhoidea) Fauna. Archives of Biological Sciences, Belgrade, 66 (4): 1473-1478. 
TAŞAR G. E. 2018. Contributions to the knowledge of Aquatic Coleoptera Fauna (Dryopidae, Helophoridae, Heteroceridae, Hydrochidae, Hydrophilidae, Gyrinidae, Haliplidae and Noteridae) of Diyarbakır, Mardin and Batman Provinces (Turkey). Turkish Journal of Fisheries and Aquatic Sciences 18: 927-936. DOI: 10.4194/13032712-v18_8_01

VAnin S. A., Costa C., Ide S. \& Beutel R. G. 2016. Heteroceridae MacLeay, 1825. Pp. 612-615. In: Beutel R. G. \& LESCHEN R. A. B. (eds), Handbook of zoology. Volume IV (Arthropoda: Insecta), Part 38. Coleoptera, Beetles. Volume 1: Morphology and Systematics (Archostemata, Adephaga, Myxophaga, Polyphaga partim). 2nd ed. Berlin, Boston: Walter de Gruyter. XVII+684 pp.

\section{STRESZCZENIE}

\section{[Nowe stwierdzenia chrząszczy różnorożkowatych (Coleoptera: Heteroceridae) w Wietnamie]}

W artykule przedstawiono wyniki badań nad fauną różnorożkowatych (Heteroceridae) Wietnamu. Analizowany materiał został zebrany podczas rosyjsko-wietnamskich ekspedycji do roku 2018 i jest przechowywany w zbiorach Rosyjskiej Akademii Nauk w Instytucie Wód Śródlądowych w Boroku oraz w Instytucie Zoologicznym w St.-Petersburgu. Przedstawiona lista zawiera 11 gatunków chrząszczy z tej rodziny, gdyż uzupełniły ją dwa nowe stwierdzenia: Augyles gabriellae (Mascagni, 1993) oraz ostatnio opisany Augyles letovi Sazhnev, 2018. 